\title{
Economic Growth and Defense Spending in Greece, Turkey and Cyprus: Evidence from Cointegrated Panel Analysis
}

\author{
Stylianou Tasos ${ }^{1}$
}

This paper investigates the nexus between economic growth and defense spending for three adjacent countries, namely Greece, Turkey and Cyprus. Greece and Cyprus, members-countries of European Union spend much more money than other member countries of EU relatively to their GDP. Turkey is in accession negotiations with EU and is among the top 15 countries with the highest military expenditure. These three countries are particularly interesting case studies because of their bigh military burdens and the bad relations between them (Greece and Cyprus opposite Turkey). The empirical analysis is based on panel data analysis of data over the period 1960 - 2006.

Keywords: Economic growth; Defense spending, Panel Data, Unit Root, Cointegration

JEL Classifications: A10; C23

${ }^{1}$ Stylianou Tasos, University of Macedonia, Department of Applied Informatics, Email : tasosstylianou@gmail.com 


\section{Introduction}

In Defense Economics Literature, the impact of defense expenditures on growth has been a major problem among the economists and until now it has not been fully investigated. Despite the large body of empirical literature there is still controversy about whether defense expenditure causes a lower or higher growth rate.

Greece, Turkey and Cyprus are some of the countries that are spending huge amounts on defense each year, despite of the general trend (in the post Cold War) witch shows reduced defense expenditure world wide. The huge amounts spend are mainly as a result of security issues. Greece and Turkey are being in trouble from the ancient years and these older enmities are continuing and after the Cold War. The history of both countries is full of invasions the other. Cyprus is the major fact of contention between Turkey and Greece. The summer of 1974 Turkey invade to the northern part of island and now holds 40\% (about) of Cyprus territory. Except from 1974 Turkey and Greece have been in many numerous war situations such as 1964, 1967, 1976 and 1996 over Cyprus. All these situations led the three countries to increase their military spending.

\section{THEORETICAL AND EMPIRICAL APPROACHES}

The first investigations of the growth-defense relationship were made by Benoit (1978) who stated that expenditures may lead to growth by "providing education and medical care, decreasing unemployment rate, engaging in variety of public works, scientific and technical innovations." His finding provoked criticism and attracted the interest among the researchers. 
In the general framework of literature review we have three groups arguing about the relationship between defense expenditures and growth. From one part we have the group supporting the neoclassical approach. In this group the economists found that defense expenditures deter economic growth and they have negative correlation (Değer \& Smith, 1983; Shieh et al 2002). In the second group we have the authors supporting the Keynesian Theory. They have founded that the impact of defence expenditures to growth is positive (Benoit, 1978; Atesoglu, 2004). The third group supports that the net effect of this relationship can't be consistent and we can't generalize it for all the countries. The net effect may vary from positive to negative (Looney, 1988b, Chowdhury, 1991; Karakul \& Palaz, 2004).

Some possible ways of grouping the literature review could be,

$>$ Depending on the correlation results of defence expenditure and growth.

$>$ Data used and the sample

$>$ The methods used and

$>$ The significance of results

Different methods have been applied to understand the relationship between defense and growth. In the literature review the most used methods are: Cross-section analysis (Benoit, 1978; Değer \& Smith 1983; Biswas \& Ram, 1986; Değer, 1986; Looney, 1988b), time series regression analysis (Looney, 1989; Chowdhury, 1991), and data panel analysis (Kollias et al 2007, Rudra Prakash Pradhan 2010, Habibullah et al 2009).

From the defense economics literature review there is a common sense that we cant generalize the relationship between defense expenditures and growth, so the defense economists have 
tried to find common features for similar countries and group them upon their commonalities such as: conflicted and non conflicted states (Looney, 1988b), low growth / high growth developed and developing countries (Benoit, 1978; Değer, 1986; Dakurah et al, 2001), and the sensitivity of a region sensitivity (Kollias, 1995; Kollias \& Makrydakis, 1997; Dritsakis 2004).

As a result from all above and the diverse literature we can't indicate robust empirical regularity positive or negative (Dunne at al 2004). Also, that relationship cannot be generalized over the time and across the countries.

\section{GREECE, TURKEY AND CYPRUS: DEFENCE SPENDING AND ECONOMY}

\subsection{Economy}

Figure 1 represents the growth rates of Greece, Turkey and Cyprus for the years 1960 - 2006. The 1960s was the "the golden period" of Greek economy with tremendous growth, high productivity and large investments from domestic savings. During the period of dictatorship (1967-1974) the inflation has increased, the debt has been tripled and the growth rates have been decreased. Furthermore the Greek economy had to face and the consequences of the Turkish invasion to Cyprus (1974). The next 10 years the country had the smallest (and sometimes negatives) growth rates of its history. The economic problems had been deteriorated. The year 1981 was very important for the history of Greece; it was the year that the country became member of the European Community. During the 1990s, the Greek economy had a slight improvement and managed to achieve the criteria to join the EMU. Since then the economy remains weak and below the EUs average. 
Figure 1

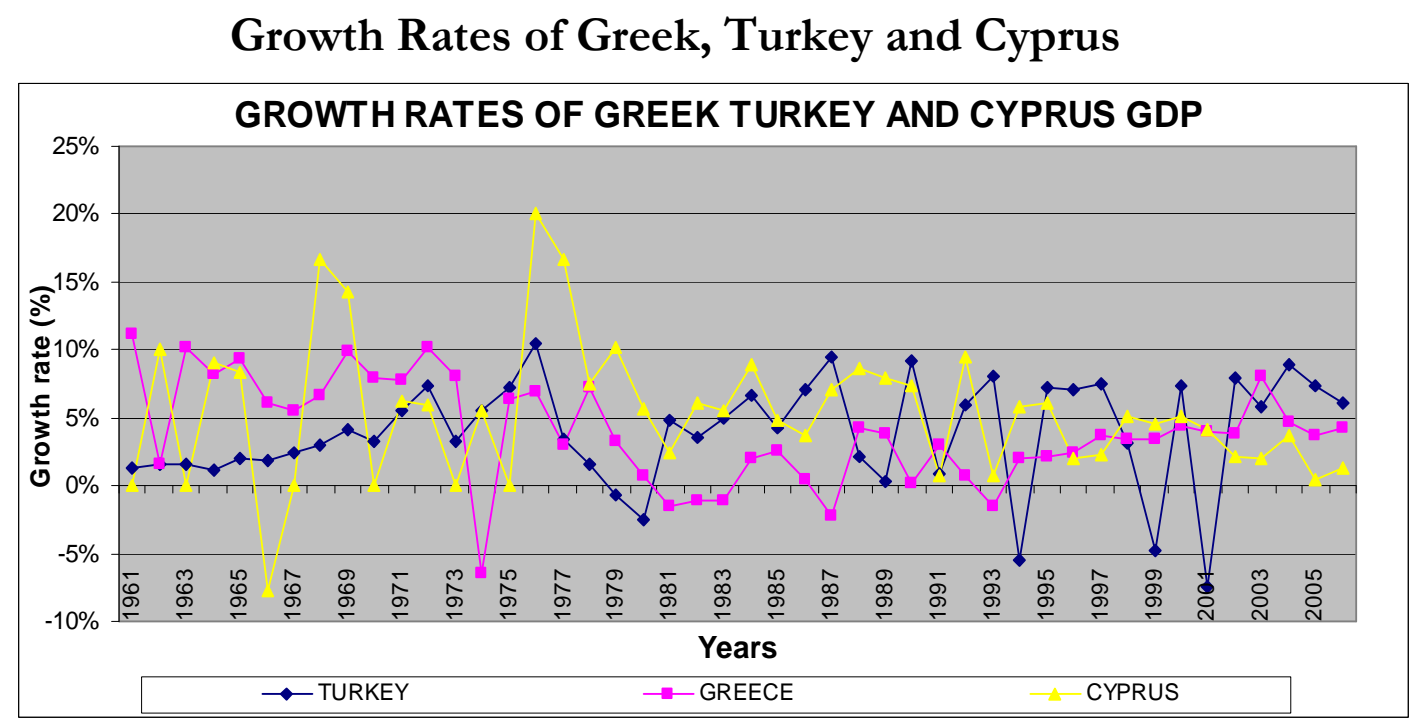

Turkey is a country that is following a policy of industrialization within a closed economy. The economy is an inward - oriented with a high degree of protectionism. The government is playing an essential role with high intervention. The 1960s was a complicated period for Turkey with high inflation, unemployment and a gap in the foreign accounts. The oil crisis during 1973 had a damaging effect to the economy and the invasion of Cyprus in 1974 caused decline in the growth rates. In 1981 Turkey had high economic growth and reduction in inflation. Although there was high economic growth during the last 20 years Turkey is facing serious economic problems like inflation and unemployment. Furthermore Turkey has to face many security concerns that lead the economy to fluctuations. 
Cyprus became independent country in 1960 and faced a number of structural problems. Since 1974 the economy of Cyprus performed well overall and there was an increase to the GDP (except the year 1966 because of the inter-communal conflictions). The Turkish invasion in 1974 caused serious problems to the economy of the island such as high inflation and interest rates, unemployment etc. The last two decades Cyprus moved from agriculture based towards service oriented structure with tourism the main financial activity. With low interest and inflation rates, a highly developed financial sector Cyprus is now a member of EU transforming the economy into a modern and liberal economy with high growth rates.

\subsection{Military Expenditures}

Figure 2 shows the military expenditures for the three countries as a percentage of GDP. Clearly 1974 was a critical year for the 3 countries. The Turkish invasion of Cyprus in that year caused an increase to the military expenditures which remained high for some years due to the conflictions.

Greece, during the last years is trying to reduce the defense expenditures but the ratio is still higher from EU average due to security concerns (conflicts with Turkey in Aegean Sea, Cyprus). From the other hand, Turkey is one of the major defense spenders in the world and this has to do with the significant security concerns it has to face apart from Greece (external threats from Kurdish separists, Iraq, Iran and Syria). Finally, Cyprus in the last decade is following the downward trend of the total world defense spending. The critical years for Cyprus were 1974 (the Turkish invasion) and the decade 19871998 (the crisis of Imia and the incidents with Isaak and Solomou). 
Figure 2

\section{Military Expenditures as percentage of GDP}

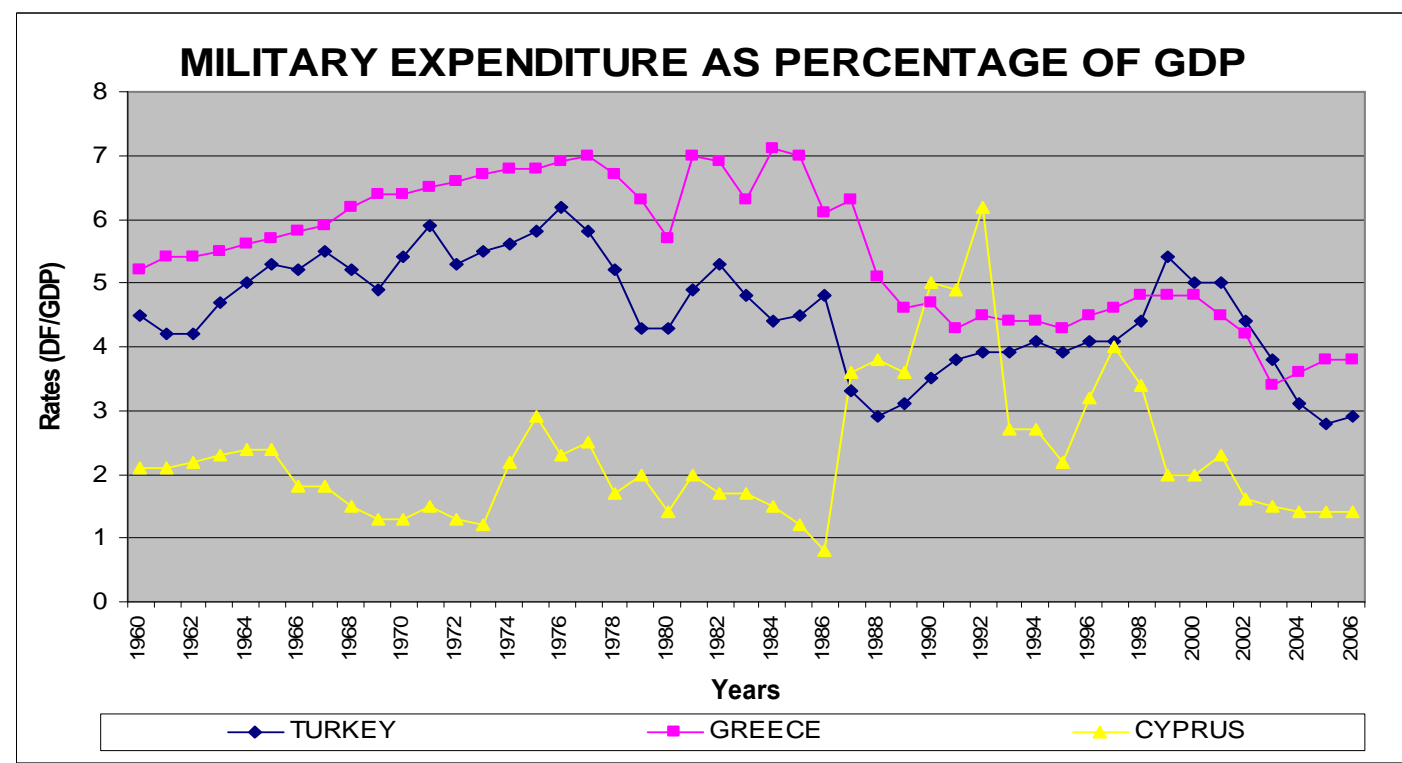

\section{DATA SPECIFICATION OF THE MODEL}

For the analysis of defense spending for the three countries the following model has been used:

$$
D S_{t}=\alpha_{0}+\alpha_{1} Y_{t}+\varepsilon_{t}
$$

The panel version of Equation (1) can be written as follows:

$$
D S_{i t}=\beta_{0 i}+\beta_{1 i} Y_{i t}+\varepsilon_{i t}
$$

DS represents the defense spending $\mathrm{Y}$ represents real GDP, and $\varepsilon$ is the error term with the conventional statistical properties (Paresh Kumar Narayan and Russell Smyth 2007) Equation (2) was estimated for Greece, Turkey and Cyprus using annual data for the period 1960 to 2006. Data on the military expenditure is from Stockholm Year XV no. 44 
International Peace Research Institute (SIPRI) and on GDP from UNESCO. The list of variables that have been used in the panel analysis for the three countries are:

LMILEX: Logarithm of Military Expenditures

LGDP: Logarithm of GDP

\section{ECONOMETRIC METHODOLOGY}

For the estimation of Equation (2) we use panel unit root tests and panel cointegration. With the usage of panel data we can exploit both and the time series dimensions of the data and the cross-sectional dimensions. If all or any from the variables we use (DS,GDP) are nonstationary, the panel data estimations will be spurious such as the effect of the defence expenditures on the growth (Dunne, PerloFreeman \& Soydan, 2004). With panel cointegration and panel unit root tests we avoid the problem of spurious regressions because of the examining the order of integration of the variables and if we find them non-stationary then we test them if they are cointegrated. If we find that they are cointegrated then a linear combination of the nonstationary variable will be stationary.

In this paper first, we examine whether our variables contain a panel unit root. Then if they cointan a panel unit root we examine whether we have a panel cointegration.

\subsection{Panel Data Unit Root Tests}

From the many and different panel data unit root tests we have chosen the tests proposed by Breitung (2000), Im, Pesaran \& Shin (2003), Hadri (2000) and Levin et al. (2002) (LLC). In the Hadri test the null hypothesis is that the variable is stationary. 
In the LLC test we have a panel-based ADF test that restricts parameters $\gamma_{i}$ by keeping them identical across cross-sectional regions. The above are expressed in the following equation:

$$
\Delta y_{i t}=c_{i}+\gamma_{i} y_{i, t-1}+\sum_{j=1}^{k} c_{j} \Delta y_{i, t-j}+e_{i, t}
$$

Where $\mathrm{t}=1, \ldots, \mathrm{T}$ time periods and $\mathrm{i}=1, \ldots, \mathrm{N}$ members of the panel. The null hypothesis for the LLC test is that $\gamma_{1}=\gamma_{2}=\gamma=0$ for all $i$, and the alternative is that $\gamma_{1}=\gamma_{2}=\gamma \prec 0$ for all $i$. The test is based on the statistics $t_{\gamma}=\frac{\hat{\gamma}}{\text { s.e( }(\hat{\gamma})}$

The test assumes homogeneity in the dynamic of the AR coefficients for all panel members. Also the LLC test allows the introduction of lags of the dependent variables to allow for serial correlation in the errors.

The IPS test (Im et al., 2003) allows individual effects, time trends, and common time effects for heterogeneous panels. The test is based on individual Augmented Dickey-Fuller (ADF) regressions and allows heterogeneity between units in a dynamic panel framework. The model they proposed is:

$$
\Delta Y_{i t}=\rho_{i} y_{i t-1}+\sum_{k=1}^{p t} \gamma_{i k} \Delta Y_{i t-k}+Z_{i t} \delta+\varepsilon_{i, t}
$$

where $p$, is the number of lags for correlation free residuals

Zit shows the vector of determinist variables in the model including fixed effects or individual trends

Yit lies for each variable under consideration in the model and

$\delta$ is the corresponding vector of the coefficients. The null hypothesis is that each series in the panel contains a unit root, i.e., $\mathrm{H}_{0}: \varrho \mathrm{i}=0$ for 
all $i$ and the alternative hypothesis allows for some (but not all) of the individual series to have unit roots, i.e.,

$$
H_{1}= \begin{cases}\rho_{i} \prec 0 \text { for } & i=1,2, \ldots \ldots, N_{1} \\ \rho_{i}=0 \text { for } & i=N_{1}+1, \ldots, N\end{cases}
$$

$\mathrm{N}$ is the number of cross sections

The IPS proposed and the use of a t-bar statistic which is defined as the average of the individual ADF statistics as:

$$
\bar{t}=\frac{1}{N} \sum_{i=1}^{N} t_{\rho_{i}}
$$

Where $t_{\rho i}$ is the t-statistic for testing the null hypothesis.

If we accept the null hypothesis then all series in the panel are nonstationary. If we accept the alternative then a fraction of the series in the panel is assumed to be stationary.

$>$ Breitung (2000) finds that the LLC and IPS tests suffer from a dramatic loss of power if individual-specific trends are included. So he proposed a t-ratio type test statistic for testing a panel unit root. Through Monte Carlo experiments and numerical analysis, he claimed that his test has 'nice' power properties within a certain local neighbourhood of unity. The difference between the Levin, Lin \& Chu (2002) test and the Breitung (2000) test is that the LLC test requires bias correction factors to correct for crosssectionally heterogeneous variances to allow for efficient pooled OLS estimation, while the Breitung (2000) test achieves the same result by appropriate variable transformations (Dunne, Perlo-Freeman \& Soydan, 2004).

$>\quad$ Hadri (2000) derives a residual-based Lagrange multiplier (LM) test where the null hypothesis is that there is no unit root in any of the series in the panel against the alternative of a unit root in the panel. This is a generalization of the KPSS test from time series to panel 
data. It is based on OLS residuals of Yit on a constant, or on a constant and a trend (Baltagi, 2005).

\subsection{Panel Cointegration Tests}

When we are differencing the data we are preventing the spurious regression problem. From the other hand it may also cause the loss of the long term information that the series may contain. With panel cointegration analysis "even though the series themselves may contain stochastic trends (i.e. non-stationary), they will nevertheless move together over time and the difference between them will be stable (i.e. stationary)",(Harris,1995:22) we can examine the data to find the long-term information the series may include.

In this paper three types of panel cointegration are implemented. The first test developed by Pedroni (1999, 2004), and the residual based panel cointegration test by Kao (1999).

- Pedroni(1999) developed seven test statistics to test the null of no cointegration between two variables.; The seven component tests are: the panel vtest, panel rho-test, panel PP-test, panel ADF-test, group rho-test, group PP-test, and group ADF-test.

$>\quad$ Panel v statistic

$$
T^{2} N^{3 / 2} Z_{\hat{V} N, T} \equiv T^{2} N^{3 / 2}\left(\sum_{i=1}^{N} \sum_{t=1}^{T} \hat{L}_{11 i}^{-2} \hat{e}_{i, t-1}^{2}\right)^{-1}
$$

The panel rho-test statistic

$$
T \sqrt{N} Z_{\hat{\rho} N, T} \equiv T \sqrt{N}\left(\sum_{i=1}^{N} \sum_{t=1}^{T} \hat{L}_{11 i}^{-2} \hat{e}_{i, t-1}^{2}\right)^{-1} \sum_{i=1}^{N} \sum_{t=1}^{T} \hat{L}_{11 i}^{-2}\left(\hat{e}_{i, t-1} \Delta \hat{e}_{i, t}-\hat{\lambda}_{i}\right)
$$

The panel t statistic (Non-parametric)

$$
Z_{t N, T} \equiv\left(\tilde{\sigma}_{N, T}^{2} \sum_{i=1}^{N} \sum_{t=1}^{T} \hat{L}_{11 i}^{-2} \hat{i}_{i, t-1}^{2}\right)^{-1 / 2} \sum_{i=1}^{N} \sum_{t=1}^{T} \hat{L}_{11 i}^{-2}\left(\hat{e}_{i, t-1} \Delta \hat{e}_{i, t}-\hat{\lambda}_{i}\right)
$$


The panel $t$ statistic (parametric)

$Z_{t N, T}^{*} \equiv\left(\tilde{S}_{N, T}^{* 2} \sum_{i=1}^{N} \sum_{t=1}^{T} \hat{L}_{11 i}^{-2} \hat{e}_{i, t-1}^{* 2}\right)^{-1 / 2} \sum_{i=1}^{N} \sum_{i=1}^{T} \hat{L}_{11 i}^{-2}\left(\hat{e}_{i, t-1}^{*} \Delta \hat{e}_{i, t}^{*}\right)$

The group $Q \square$ statistic (parametric)

$$
T N^{-1 / 2} \tilde{Z}_{\tilde{\rho} N, T-1} \equiv T N^{-1 / 2} \sum_{i=1}^{N}\left(\sum_{t=1}^{T} \hat{e}_{i, t-1}^{2}\right)^{-1} \sum_{t=1}^{T}\left(\hat{e}_{i, t-1} \Delta \hat{e}_{i, t}-\hat{\lambda}_{i}\right)
$$

The group t statistic (non-parametric)

$$
N^{-1 / 2} \tilde{Z}_{t N, T-1} \equiv N^{-1 / 2} \sum_{i=1}^{N}\left(\hat{\sigma}_{i}^{2} \sum_{t=1}^{T} \hat{e}_{i, t-1}^{2}\right)^{-1 / 2} \sum_{t=1}^{T}\left(\hat{e}_{i, t-1} \Delta \hat{e}_{i, t}-\hat{\lambda}_{i}\right)
$$

The group t statistic (parametric)

$$
N^{-1 / 2} \widetilde{Z}_{t N, T}^{*} \equiv N^{-1 / 2} \sum_{i=1}^{N}\left(\sum_{t=1}^{T} \hat{S}_{i}^{* 2} \hat{e}_{i, t-1}^{* 2}\right)^{-1 / 2} \sum_{t=1}^{T}\left(\hat{e}_{i, t-1}^{*} \Delta \hat{e}_{i, t}^{*}\right)
$$

Kao (1999)

Kao test use a similar approach as the Pedroni tests. The differences are that Kao specifies a crosssection specific intercepts and homogeneous coefficients on the first stage regressors. Also the null hypothesis is that the residuals, are non-stationary (i.e., there is no cointegration).The alternative hypothesis, the residuals are stationary (i.e., there is a cointegrating relationship among the variables).

\subsection{Long-run relationship (FMOLS)}

Finally, after finding cointegration in the third step, we estimate the coefficients on GDP by using panel fully modified ordinary least squares method (FMOLS) proposed by Pedroni (2000).

It is very important to mention that the panel cointegration tests do not provide us the estimation of the long run relationship. The fundamental economic principles involves, that the cointegration 
vector must be common for the members of the panel. Also, a very critical issue is the hypothesis testing. In fact, the nuisance parameters determine the asymptotic distribution of the OLS estimator. That problem seems to be much more serious in panel environment because the bias can accumulate with the size of the cross section. Hence, in order to overcome these deficits, efficient methods like fully modified (FMOLS) are required. The technique of FMOLS can control for potential endogeneity of the regressors and serial correlation, so asymptotically unbiased estimations of the long run can be obtained.

\section{EMPIRICAL FINDINGS}

\subsection{Panel Unit Root Tests}

As preconditions in this work, panel unit root tests and panel cointegration tests, are implemented as individual intercept and intercept and trend for all data (military expenditures (milex) and Gross Domestic Product (GDP)). The results of the panel unit root tests, which are generally used in the empirical work with the nonstationary panel variables, are in table 1 . All the variables are expressed in natural logarithms so that elasticities can also be determined. 


\section{Table 1}

\section{Panel Unit Root Tests}

\begin{tabular}{|c|c|c|c|c|c|c|c|c|}
\hline \multirow[t]{2}{*}{ VARIABLES } & \multicolumn{2}{|c|}{ LLC } & \multicolumn{2}{|c|}{ BREITUNG } & \multicolumn{2}{|c|}{ IPS } & \multicolumn{2}{|c|}{ HADRI } \\
\hline & $\tau_{\mu}$ & $\tau_{\tau}$ & $\tau_{\mu}$ & $\tau_{\tau}$ & $\tau_{\mu}$ & $\tau_{\tau}$ & $\tau_{\mu}$ & $\tau_{\tau}$ \\
\hline LGDP & $\begin{array}{c}-1.013 \\
(0.156)\end{array}$ & $\begin{array}{c}-0.393 \\
(0.347)\end{array}$ & $\ldots$ & $\begin{array}{c}-0.102 \\
(0.459)\end{array}$ & $\begin{array}{c}1.337 \\
(0.909)\end{array}$ & $\begin{array}{c}0.311 \\
(0.622)\end{array}$ & $\begin{array}{c}8.226 \\
* * * \\
(0.000)\end{array}$ & $\begin{array}{c}4.389 \\
* * * \\
(0.000)\end{array}$ \\
\hline DLGDP & $\begin{array}{c}-8.813 \\
* * * \\
(0.000)\end{array}$ & $\begin{array}{c}-8.855 \\
* * * \\
(0.000)\end{array}$ & - & $\begin{array}{c}-5.857 \\
* * * \\
(0.000)\end{array}$ & $\begin{array}{c}-8.812 \\
* * * \\
(0.000)\end{array}$ & $\begin{array}{c}-8.509 \\
* * * \\
(0,000)\end{array}$ & $\begin{array}{c}1.416 \\
*\end{array}$ & $\begin{array}{c}3.489 \\
* * *\end{array}$ \\
\hline LMILEX & $\begin{array}{c}0.581 \\
(0.581)\end{array}$ & \begin{tabular}{|c|}
-1.1940 \\
$(0.116)$
\end{tabular} & -...... & $\begin{array}{c}(0.000) \\
-0.209 \\
(0.209)\end{array}$ & $\begin{array}{c}(0.000) \\
(0.2941\end{array}$ & $\begin{array}{c}(0.000) \\
-1.134 \\
(0.128)\end{array}$ & $\begin{array}{c}(0.078) \\
1.726 \\
(0.042)\end{array}$ & $\begin{array}{c}(0.060) \\
(0.047)\end{array}$ \\
\hline DLMILEX & $\begin{array}{c}-10.873 \\
* * * \\
(0.000)\end{array}$ & $\begin{array}{c}-10.613 \\
* * * \\
(0.000)\end{array}$ & $-\cdots$ & $\begin{array}{c}-8.298 \\
* * * \\
(0.000)\end{array}$ & $\begin{array}{c}-10.001 \\
* * * \\
(0.000)\end{array}$ & $\begin{array}{c}-9.656 \\
* * * \\
(0.000)\end{array}$ & $\begin{array}{l}-0.357 \\
(0.640)\end{array}$ & $\begin{array}{c}1.343 \\
(0.090)\end{array}$ \\
\hline
\end{tabular}

Notes:

1. Panel data include all countries

2. All variables are in natural logarithms.

3. The numbers in parentheses denote $\mathrm{p}$-values

4. ***,**,* denotes rejection of null hypothesis at the $1 \%, 5 \%$ and $10 \%$ level of significance, respectively.

5. The null hypothesis of these tests is that the panel series has a unit root (nonstationary series) except with the Hadri test which has no unit root in panel series.

Table 1 shows the panel unit root test results. All tests indicate that the panel level series of the two variables are non stationary, but the first-difference series are stationary. Thus, we use the firstdifference of the two variables panel to study the cointegration tests.

\subsection{Panel Cointegration Tests}

The next step after finding that our series are stationary in the first differences, we are testing the variables for cointegration in order to determine whether there is a long-run relationship to control for in the econometric specification. We are using the Pedroni's and Kao Year XV no. 44 
tests. Table 2 shows the results of panel cointegration tests. It also compares the cases with and without trend.

Table 2

Panel Cointegration Tests

\begin{tabular}{|l|l|l|}
\hline & Constant without trend & Constant and trend \\
\hline Pedroni Residual Cointegration Tests & \\
\hline Panel Statistics & \multicolumn{2}{|l|}{} \\
\hline Panel v - Statistic & $1.040(0.149)$ & $-0.200(0.580)$ \\
\hline Panel rho - Statistic & $-2.289(0.011)^{* *}$ & $-2.232(0.013)^{* *}$ \\
\hline Panel pp - Statistic & $-1.755(0.040)^{* *}$ & $-2.187(0.014)^{* *}$ \\
\hline Panel ADF - Statistic & $-1.890(0.029)^{* *}$ & $-2.317(0.010)^{* * *}$ \\
\hline Group Statistics & & \\
\hline Group rho - Statistic & $-0.548(0.292)$ & $-0.659(0.255)$ \\
\hline Group pp - Statistic & $-0.756(0.225)$ & $-1.062(0.144)$ \\
\hline Group ADF - Statistic & $-1.378(0.084)^{*}$ & $-1.872(0.031)^{* *}$ \\
\hline Kao Residual Cointegration Tests \\
\hline ADF- Statistic & $-1.743(0.041)^{* *}$ \\
\hline
\end{tabular}

Notes:

1. The test statistics are distributed as $\mathrm{N}(0,1)$.

2. The variance ratio test (Panel $v-$ Statistic) is right sided, while the others are left-sided.

3. ***, ** and $*$ denotes significance respective at the $1 \%, 5 \%$ and $10 \%$ level.

4. The critical value is $-1,64$ except $\mathrm{v}$-statistic which has 1,64

Almost all statistics reject the null of no cointegration. An exception is the Group rho - Statistic and Group pp - Statistic. We conclude that the variables are cointegrated.

\subsection{Panel FMOLS Estimates}

Given that the variables are cointegrated we are moving to the next step to find the estimation for the long-run relationship. 


\section{Table 3}

Panel FMOLS Estimates

\begin{tabular}{|l|l|}
\hline COUNTRY & LGDP \\
\hline Greece & $-0.268[0.0273]^{* *}$ \\
\hline Turkey & $-0.231[0.0035]^{* * *}$ \\
\hline Cyprus & $0.127[0.3329]$ \\
\hline Panel & $0.223[0.0000] * * *$ \\
\hline
\end{tabular}

Notes: 1 . The numbers in parentheses denote $\mathrm{p}$-values

2. ***,**,* denotes rejection of null hypothesis at the $1 \%, 5 \%$ and $10 \%$ level of significance, respectively.

The elasticity of GDP for the panel of the three countries is significantly estimated at a positive value of 0.223 . From the results above we can see that the use of panel data for the three countries supports a cointegration relationship, and we can conclude that the existence of the military expenditure function is statistically supported. The FMOLS estimations are statistically significant and negative for Greece and Turkey which means that military expenditures affect growth.

\section{ConClusions}

In this paper we explore the relationship between defense spending and economic growth between three countries, namely Greece, Turkey and Cyprus, over the period 1960- 2006. The empirical investigation has been carried out with a panel of three Mediterranean countries. It also explores the cointegration between these countries. The main findings of this study are summarized as follows:

1). Economic growth and defense spending are integrated of order one (using unit root tests such as LLC, Breitung, IPS and Hadri. 
2) Pedroni's panel cointegration tests and Kao Residual Cointegration Tests confirmed that there is evidence of cointegration. This suggests that long run relationship between defense spending and economic growth exists in the three countries.

3) There is solid evidence in the case of the three countries under consideration, that there is a panel cointegration relation between growth and military expenditures.

\section{References:}

Ateşoglu, H. S. (2004). "Defense spending and investment in the United States". Journal of Post Keynesian Economics, 27(1), 163.

Baltagi, B.H. (2005) "Econometric Analysis of Panel Data", John Wiley and Sons, third edition.

Benoit, E. (1978), "Growth and defence in developing countries", Economic Development and Cultural Change, Vol. 26, pp.261-80.

Breitung, Jörg, 2000. "The Local Power of Some Unit Root Tests for Panel Data", Advances in Econometrics, 15: 161-177.

Chowdhury, A. R. (1991). "A causal analysis of defense spending and economic growth". The Journal of Conflict Resolution, 35(1), 80-97.

Dakurah, A. H., Davies, S. P., \& Sampath, R. K. (2001). "Defense spending and economic growth in developing countries: A causality analysis". Journal of Policy Modeling, 23(6), 651-658.

Deger, S. and Sen, S. (1983), "Military expenditures, spin-off and economic development", Journal of Development Economics, Vol. 13, pp.68-83.

Dickey, D. A. and Fuller, W. A., 1979, "Distributions of the estimators for autoregressive time-series with a unit root". Journal of the American Statistical Association, 74 (3), 427-431. 
Dritsakis N. (2004). «Defense spending and economic growth: An empirical investigation for Greece and Turkey using Granger analysis». Journal of Policy Modeling, Vol. 26, pp. 249 - 264

Dunne, J, Soydan, A, Perlo-Freeman, (2004), "Military Expenditure and Debt in South America", Defence and Peace Economics Vol. 15, No. 2, pp. 173-187

Dunne, P., R. Smith and D. Willenbockel (2004) "Theoretical and econometric issues in analysing the military expenditure-growth nexus", Mimeograph".

Habibullah Muzafar Shah, Hirnissa Mohd Tahir, and Baharom Abdul Hamid. (2009). "Defense Spending and Income Inequality: Evidence from Selected Asian Countries". Modern Applied Science, 3(5):96-111. Hadri, K., (2000). "Testing for Stationarity in heterogeneous panel data”. Econometrics Journal 3, pp 148-161

Harris, R.I.D(1995), 'Using Cointegration Analysis in Econometric Modeling', Essex: Prentice Hall,pp. 1-47

Im, Kyung So; M. Hashem Pesaran \& Yongcheol Shin, 2003. "Testing for Unit Roots in Heterogeneous Panels". Journal of Econometrics, 115(1): 53-74.

Kao, C. "Spurious Regression and Residual-Based Tests for Cointegration in Panel Data," Journal of Econometrics, 1999, 90, 1-44 Karagöl, E., \& Palaz, S. (2004). "Does defence expenditure deter economic growth in Turkey? A cointegration analysis". Defence and Peace Economics, 15(3), 289.

Kollias, C. (1995). "Country survey VII: Military spending in Greece". Defence and Peace Economics. Journal of Peace Research, 6(305), 319.

Kollias, C., \& Makrydakis, S. (1997). Is there a Greek-Turkish arms race? Evidence from cointegration and causality tests. Defence and Peace Economics, 8(355), 379. 
Levin, Andrew; Chien-Fu Lin and Chia-Shang James Chu, 2002. "Unit Root Tests in Panel Data: Asymptotic and Finite Sample Properties", Journal of Econometrics, 108(1): 1-24.

Looney, R. E. (1988b). "Military expenditures and socio-economic development in Africa: A summary of recent empirical research". The Journal of Modern African Studies, 26(2), 319-325.

Looney, R. E. (1989). "Impact of arms production on income distribution and growth in the third world". Economic Development and Cultural Change, 38(1), 145-153.

Paresh Kumar Narayan \& Russell Smyth, 2007. "The Military Expenditure-External Debt Nexus: New Evidence From A Panel Of Middle Eastern Countries," Monash Economics Working Papers 17/07.

Pedroni P. (1999), 'Critical Values for Cointegration Tests in Heterogeneous Panels with Multiple Regressors' Oxford Bulletin of Economics and Statistics, Special Issue 0305-9049

Pedroni, Peter, 2000. 'Fully Modified OLS for Heterogeneous Cointegrated Panels', Advances in Econometrics, 15: 93-130.

Pedroni, Peter, 2004. 'Panel Cointegration: Asymptotic and Finite Sample Properties of Pooled Time Series Tests with An Application to PPP Hypothesis: New Results', Econometric Theory, 20(3): 597-627.

Rudra Prakash Pradhan (2010), Defense Spending and Economic Growth in China, India, Nepal and Pakistan: Evidence from Cointegrated Panel Analysis. International Journal of Economics and Finance, Vol 2, No 4, 65-74

Shieh, J., Lai, C., \& Chang, W. (2002). "The impact of military burden on long-run growth and welfare". Journal of Development Economics, 68(2), 443. 
